\title{
Infant readmission was related to early discharge, young gestational age, and breast feeding
}

\author{
Maisels MJ, Kring E. Length of stay, jaundice, and hospital readmission. Pediatrics 1998 Jun;101:995-8.
}

\section{Question}

Is a newborn infant's age at discharge associated with hospital readmission for hyperbilirubinaemia?

\section{Design \\ Case control study.}

\section{Setting}

A large community hospital associated with a university in Detroit, Michigan, USA.

\section{Participants}

In a 6 year period, 127 newborn infants were readmitted to hospital because of hyperbilirubinaemia within 14 days of discharge from the well baby nursery. Control participants were 127 infants discharged in the same year who were not readmitted.

\section{Assessment of risk factors}

Maternal type 1 diabetes mellitus, maternal smoking, gestational age at birth $(\leqslant 36,36-37,>37-38,>38-39,>39-<40$, and $\geqslant 40 \mathrm{wk}$ ), jaundice before discharge, breast feeding status, male sex, rupture of membranes $\geqslant 18$ hours before birth, meconium, and hospital length of stay $(<48,48-<72$, and $\geqslant 72 \mathrm{~h}$ ).

\section{Main outcome measure}

Hospital readmission for hyperbilirubinaemia within 14 days of discharge.

\section{Main results}

An increased risk of hospital readmission for hyperbilirubinaemia was associated with gestational age $\leqslant 36$ weeks $(\mathrm{p}<0.001)$, $>36-37$ weeks $(\mathrm{p}<0.001)$, or $>37-38$ weeks $(\mathrm{p}<0.001)$; jaundice in nursery $(\mathrm{p}<0.001)$; breast feeding $(\mathrm{p}<0.001)$; initial length of stay $48-<72$ hours $(\mathrm{p}<0.005)$ or $<48$ hours $(p=0.027)$; and male sex $(p=0.007)$. A decreased risk of readmission was associated with gestation $\geqslant 40$ weeks $(p=0.001)$, initial length of stay $\geqslant 72$ hours $(p=0.009)$, no meconium $(p=0.006)$, or rupture of membranes $\geqslant 18$ hours before birth $(\mathrm{p}=0.004)$.

\section{Conclusions}

An increased risk of hospital readmission for hyperbilirubinaemia was associated with gestational age $\leqslant 38$ weeks, jaundice before discharge, breast feeding, initial length of stay $<72$ hours, and male sex. A decreased risk was associated with gestation $\geqslant 40$ weeks, initial length of stay $\geqslant 72$ hours, no meconium, or rupture of membranes $\geqslant 18$ hours before birth.

Risk factors for infant hospital readmission for hyperbilirubinaemia

\begin{tabular}{|c|c|c|c|}
\hline Variables & Study group $(\%)$ & Control group (\%) & Odds ratio $(95 \% \mathrm{CI}$ \\
\hline $\begin{array}{l}\text { Gestational age } \leqslant 36 \\
\text { weeks }\end{array}$ & 9.5 & 1.6 & 13.2 (2.7 to 64.6 ) \\
\hline Jaundice in nursery & 90.6 & 55.9 & 7.8 (3.4 to 18.0$)$ \\
\hline $\begin{array}{l}\text { Gestational age } \\
>36-37 \text { weeks } \\
\text { Gestational age }\end{array}$ & 16.5 & 4.7 & 7.7 (2.7 to 22.0$)$ \\
\hline $\begin{array}{l}>37-38 \text { weeks } \\
\text { Breast feeding }\end{array}$ & $\begin{array}{l}28.4 \\
89.0\end{array}$ & $\begin{array}{r}8.7 \\
63.8\end{array}$ & $\begin{array}{l}7.2 \text { (3.1 to } 17.0) \\
4.2 \text { (1.8 to } 9.9)\end{array}$ \\
\hline $\begin{array}{l}\text { Breast feeding } \\
\text { Length of stay }\end{array}$ & 89.0 & 0.0 & $4.2(1.8$ to 9.9) \\
\hline $\begin{array}{l}48-<72 \text { hours } \\
\text { Male sex } \\
\text { Length of stay }<48\end{array}$ & $\begin{array}{l}44.1 \\
74.8\end{array}$ & $\begin{array}{l}33.1 \\
49.6\end{array}$ & $\begin{array}{ll}3.2 & (1.4 \text { to } 7.1) \\
2.9 & (1.5 \text { to } 5.7)\end{array}$ \\
\hline $\begin{array}{l}\text { hours } \\
\text { Gestational age } \geqslant 40\end{array}$ & 47.2 & 46.5 & 2.4 (1.1 to 5.3$)$ \\
\hline $\begin{array}{l}\text { weeks } \\
\text { Initial length of stay }\end{array}$ & 15.8 & 34.7 & $0.4 \quad(0.2$ to 0.7$)$ \\
\hline $\begin{array}{l}\geqslant 72 \text { hours } \\
\text { No meconium }\end{array}$ & $\begin{array}{l}8.7 \\
3.2\end{array}$ & $\begin{array}{l}20.5 \\
22.8\end{array}$ & $\begin{array}{ll}0.4 & (0.2 \text { to } 0.8) \\
0.2 & (0.04 \text { to } 0.6)\end{array}$ \\
\hline $\begin{array}{l}\text { Rupture of } \\
\text { membranes } \geqslant 18 \\
\text { hours before birth }\end{array}$ & 1.6 & 7.1 & $0.08(0.01$ to 0.5$)$ \\
\hline
\end{tabular}

Source of funding: no external funding.

For correspondence:Dr M J Maisels, Department of Pediatrics, William Beaumont Hospital, 3601 W 13 Mile Road, Royal Oak, MI 48073-6769, USA. Fax +12485515998.

\section{Commentary}

The consequences of early discharge of new mothers and their infants are complex. Shorter maternity stays are now common because of consumer demand to demedicalise birth and to reduce medical costs. ${ }^{1}$ Follow up in the community is piecemeal depending on the jurisdiction of practice. It is for this reason that the results of the study by Maisels and Kring must be reviewed by practitioners with an understanding of their own practice.

Concern has led to retrospective chart review studies to ascertain the relative risk of readmission of newborn infants. Jaundice has consistently been the primary diagnosis for readmission. ${ }^{23}$ Although legislation in the US may prevent further reductions in length of maternity stays, the primary issue for healthcare providers is identifying the infants most at risk and taking appropriate action. Identification of infants at risk (ie, infants $<37 \mathrm{wk}$ gestation, jaundiced before discharge, and breast fed) allows healthcare professionals to direct follow up in the community. One cannot overstate the importance of timely intervention in hospital to ensure that breast feeding methods are appropriate and that adequate information about child care is provided.

The design of the study was appropriate to assess the risk of readmission. Case and control infants were matched and all readmissions were included in the study. The authors acknowledged that retrospective studies rely on accurate data collection and missing data can be a problem. In jurisdictions where all infants are visited regularly in the community during their first few days of life, the study serves as a reminder to providers to assess the infants most at risk from early discharge. For practitioners who work in areas where postnatal visits are not routine, it is important to refer families to suitable follow up care.

Jenny Medves, RN, RGN Faculty of Nursing University of Alberta Edmonton, Alberta, Canada

1 Braveman P, Kessel W, Egerter S, et al. JAMA 1997;278:334-6.

2 Seidman DS, Stevenson DK, Ergaz A, et al.Pediatrics 1995;96:727-9.

3 Liu LL, Clemens CJ, Shay DK, et al. JAMA 1997 23;278:293-8. 